13 (2020) 3: 291-323

ISSN (print) $1689-5150$

ISSN (online) 2450-7059

\title{
W poszukiwaniu źródeł do historii całunu Jezusa. Rekonesans po piśmiennictwie chrześcijańskiego antyku i średniowiecza
}

\section{In search of sources for the history of Jesus' shroud. Exploring the literature of Christian antiquity and the Middle Ages}

Streszczenie. W badaniach syndonologicznych, skupionych na całunie turyńskim, podejmowane są także studia nad jego historią. Na ogół przyjmuje się, że źródłowo udokumentowany jest okres od połowy XIV wieku, gdy całun znalazł się we francuskim Lirey, nieopodal Troyes. Wcześniejsze jego losy są wysoce hipotetyczne, albo wręcz nieznane. W niniejszym artykule podjęta zostanie próba prześledzenia źródeł literackich, w których pojawia się topos całunu Jezusa i jego wizerunku w antyku chrześcijańskim, oraz powiązania ich z płótnem, znajdującym się obecnie w katedrze turyńskiej. Przedmiotem badań stały się cztery grupy źródeł: (1) ewangelie kanoniczne przyjęte przez Kościół i patrystyczne do nich komentarze, (2) chrześcijańska literatura apokryficzna okresu starożytnego i średniowiecznego, podejmująca topos całunu oraz (3) wizerunku Jezusa, (4) a także wczesne itineraria chrześcijańskich pielgrzymów odwiedzających Ziemię Świętą (ojczyznę Jezusa i apostołów), w których mowa o całunie, oraz pomocniczo wybrane artefakty, łączące się z przekazami zawartymi w tych źródłach.

\begin{abstract}
In syndonological studies focused on the Turin Shroud, studies on its history are also undertaken. It is generally accepted that the period is documented from the mid-fourteenth century, when the shroud was in French Lirey near Troyes. His earlier fate is highly hypothetical or even unknown. In this article an attempt will be made to trace literary sources in which the topos of Jesus' shroud and his image in general in Christian antiquity appear, and to link them to the canvas currently in the Turin cathedral. Four groups of sources became the subject of research: (1) canonical gospels adopted by the Church and patristic comments to them, (2) Christian apocryphal literature of the ancient and medieval times, taking the topos of the shroud and (3) the image of Jesus, (4) as well as early itineraries Christian pilgrims visiting the Holy Land (the homeland of Jesus and the apostles), in which the shroud is mentioned, as well as auxiliary artifacts selected with the messages contained in these sources.
\end{abstract}


Słowa kluczowe: historia chrześcijaństwa; apokryfy chrześcijańskie; całun Jezusa; syndonologia.

Keywords: history of Christianity; Christian apocrypha; Jesus' shroud; syndonology.

$\mathrm{W}$ badaniach syndonologicznych, skupionych na całunie turyńskim, podejmowane są także studia nad jego historią. Na ogół przyjmuje się, że źródłowo udokumentowany jest okres od połowy XIV wieku, gdy całun znalazł się we francuskim Lirey, nieopodal Troyes. Wcześniejsze jego losy są wysoce hipotetyczne, albo wręcz nieznane. W niniejszym artykule podjęta zostanie próba prześledzenia źródeł literackich, w których pojawia się topos ${ }^{1}$ całunu i wizerunku Jezusa w antyku chrześcijańskim, oraz powiązania ich z płótnem, znajdującym się obecnie w katedrze turyńskiej, którego europejska historia wiedzie różnymi, nierozpoznanymi dotąd drogami, do Lirey, a następnie docelowo do Turynu. W założeniu niniejsze badania zmierzają do rozpoznania starożytnych i średniowiecznych dziejów całunu Jezusa.

Przedmiotem badań staną się cztery grupy źródeł: (1) ewangelie kanoniczne przyjęte przez Kościół i patrystyczne do nich komentarze, (2) chrześcijańska literatura apokryficzna okresu starożytnego i średniowiecznego, podejmująca topos całunu oraz (3) wizerunku Jezusa, (4) a także wczesne itineraria chrześcijańskich pielgrzymów odwiedzających Ziemię Świętą (ojczyznę Jezusa i apostołów), w których mowa o całunie, oraz pomocniczo wybrane artefakty, łączące się z przekazami zawartymi w tych źródłach.

\section{Całun w ewangeliach kanonicznych i w patrystycznych do nich komentarzach}

\subsection{Ewangelie kanoniczne}

Wczesne chrześcijaństwo, po czterdziestu latach istnienia, zaczęło na piśmie utrwalać opowiadania o wydarzeniu Jezusa, nadając narracjom formę między innymi ewangelii, będącej przede wszystkim przepowiadaniem wzywającym do wiary lub ją utrwalającym (kerygmatem), zakorzenionym w przekazie

1 Topos oznacza tutaj przyjmowaną konwencję literacką, wyrażaną przez podobne zwroty lub przedstawienia, będące przez wieki usankcjonowanym sposobem literackiego wyrazu, dotyczącym określonego tematu, w tym wypadku całunu Jezusa. 
naocznych świadków czynów i słów Jezusa. Cztery ewangelie, spośród wielu istniejących w starożytnym Kościele, zaliczone zostały z czasem do pism Nowego Testamentu, stanowiących - obok Starego Testamentu - Pismo Święte chrześcijaństwa. Czas ich powstania określa się hipotetycznie na lata od 70 do 120-150 roku. Wszystkie cztery w końcowych częściach, ukazujących śmierć Jezusa na krzyżu oraz Jego pochówek i zmartwychwstanie, mają wprowadzone do historyczno-teologicznej narracji wzmianki o całunie, tj. płótnie lub płótnach pogrzebowych, w które zostało owinięte ciało Jezusa przed złożeniem do grobu. Należy przy tym pamiętać, że czynności z tym związane wpisują się w funeralny rytuał żydowski, jaki obowiązywał w pierwszym wieku naszej ery w Palestynie, w którym wydarzenie Jezusa miało miejsce, i co zostało wprost odnotowane w Ewangelii według Jana 19,40 („stosownie do żydowskiego sposobu grzebania”). Zgodnie z tym zwyczajem ciało zmarłego Żyda zawijano w całun zwany po hebrajsku tachrichin. Zwykle był on wykonany z jedwabiu, lnu lub bawełny. W żydowskiej kulturze końca okresu drugiej świątyni (I w. po Chr.) odpowiadał on dzisiejszej trumnie. Owo białe płótno swoją prostotą symbolizowało w judaizmie równość wobec Boga wszystkich ludzi po śmierci, zarówno bogatych, jak i biednych ${ }^{2}$.

Do tej tradycji nawiązują teksty ewangelii kanonicznych, zawierające wzmianki o całunie Jezusa. Poniżej zostały one zestawione w układzie chronologicznym, od najwcześniejszych do najpóźniejszych:

Mk 15,45-46: [Piłat] upewniony przez setnika, wydał ciało [Jezusa] Józefowi [z Arymatei]. Ten zakupił płótna [z lnu] (kai agorasas sindona ${ }^{3}$ ), zdjął Jezusa [z krzyża], owinął w płótno [z lnu] (eneilesen te sindoni) i złożył w grobie, który wykuty był w skale.

Lk 24,12: Jednak Piotr wybrał się i przybiegł do grobu; schyliwszy się ujrzał same tylko płótna (blepei ta othonia).

Mt 27,57-60: Pod wieczór przyszedł zamożny człowiek z Arymatei, imieniem Józef, który też był uczniem Jezusa. Udał się do Piłata i poprosił o ciało Jezusa. Wówczas Piłat kazał je wydać. Józef zabrał ciało, owinął je w czyste płótno (en sindonai kathara) i złożył w swoim nowym grobie, który kazał wykuć w skale.

2 Por. E. Frankel, B. Platkin Teutsch, The Encyclopedia of Jewish Symbols, s. 157.

3 M. Zerwick tłumaczy jako sindon, pannus ex lino (= sindon, płótno z lnu) - zob. Analysis philologica Novi Testamenti graeci, s. 125. W polskich tłumaczeniach oddawane jest tylko przez „płótna”. Natomiast H. Langkammer w komentarzu (Ewangelia według św. Marka, s. 354) dodaje: „[Józef] kupuje płótna lniane”. 
J 19,40: [Nikodem i Józef z Arymatei] zabrali więc ciało Jezusa i owinęli je w płótna (kai êdesan auto othoníois) razem z wonnościami, stosownie do żydowskiego sposobu grzebania.

J 20,5-7: A kiedy się nachylił [ów drugi uczeń], zobaczył leżące płótna (ta othonia), jednak nie wszedł do środka. Nadszedł potem także Szymon Piotr, idący za nim. Wszedł do wnętrza grobu i ujrzał leżące płótna (ta othonia) oraz chustę (kai to sudarion), która była na Jego głowie, leżącą nie razem z płótnami (ton othonion), ale oddzielnie zwiniętą w jednym miejscu.

W przytoczonych tekstach (oryginały po grecku) użyte zostały trzy terminy greckie na określenie płócien z grobu Jezusa: sindon (płótno) (Mt, Mk), othonia (płótno) (Łk, J), sudarion (chusta) (J). Adekwatnie ich ekwiwalentami hebrajskimi są: michse (nakrycie), sadin (płótno), tachrichin / tachrichim (płótna pogrzebowe), sudar (chusta) ${ }^{4}$. One też pojawią się w późniejszych przekazach oraz będą uzupełniane jeszcze innymi określeniami.

Hebrajskie sadin (płótno) pochodzi od egipskiego szendo, oznaczające tkaninę. W hebrajskim jest to termin nieprecyzyjny, wskazujący zwykle na kawałek wysokiej jakości płótna lnianego. W Iz 3,23 oznacza cenną szatę, a w późniejszych tekstach biblijnych specjalne prześcieradło dużych rozmiarów o przeznaczeniu liturgicznym, używane w świątyni jerozolimskiej przez arcykapłana. Określano je terminem sadin szel buc - tzn. czyste (wyłącznie) lniane płótno, w znaczeniu niezmieszane $\mathrm{z}$ innym materiałem. Szyto z niego zasłony świątyni i używał go arcykapłan po pięciokrotnym obmyciu rytualnym w Jom Kipur - Dniu Pojednania. Nie miało ono żadnych konotacji z ciałem zmarłego człowieka i jego pochówkiem.

Gdy przyszło hebrajski termin sadin przetłumaczyć na grecki, użyty w ewangeliach, poszukiwano adekwatnych terminów greckich. Podobnie brzmiało i miało zbliżone do niego znaczenie słowo sindon (duży kawałek materiału). Znamienne jest, że w Ewangelii według Mateusza nazwano materiał, którym owinięto ciało zmarłego Jezusa, płótnem czystym (en sindonai kathara) w znaczeniu „bez domieszek”, a nie „niezabrudzonym”, jak to wielu do dzisiaj rozumie. Chodzi w tym określeniu o czystość w znaczeniu duchowym i religijnym. Użyto zatem terminu należącego - o czym nie wolno zapominać - do tradycji kapłańskiej. Notabene spotykamy go również w Misznie.

4 We współczesnym wydaniu Starego i Nowego Testamentu po hebrajsku (Tanach u-Brit Chadasza, [Brith Chadasza] transl. from the Greek by Franz Delizsch; 3th ed., Jerusalem 2004) terminy greckie: sindon tłumaczony jest przez sadin, othonia przez tachrichin, a sudarion przez sudar. 
Sadin (l.mn. sedinim) odpowiada zarówno greckiemu sindon, jak i othonia, które występuje już w greckim tłumaczeniu Biblii - Septuagincie (III/II w. przed Chr.). Także w greckiej wersji dzieł Józefa Flawiusza użyto sindon na określenie świętych płócien, zdobiących przybytek Najwyższego (namiot spotkania) na pustyni oraz na odzież kapłanów.

Dobór zatem terminologii na określenie pośmiertnego płótna Jezusa nie był przypadkowy. Niemniej ten kod językowy o znaczeniu symbolicznym byli w stanie zrozumieć tylko judeochrześcijanie, obeznani z religijną terminologią judaizmu okresu drugiej świątyni. Dla nich, użyte płótno przy pochówku Jezusa, musiało kojarzyć się z szatą, którą zakładał najwyższy kapłan świątyni jerozolimskiej wyłącznie przy określonych obrzędach liturgicznych, w momencie gdy pozbył się wszelkich grzechów po długich rytach oczyszczenia.

Podobnie Janowe określenia othonia oznacza drogocenny materiał królewski, nazywany niekiedy lnem króla. Jego użycie w piśmie Jana nie jest przypadkowe. Wszystkie ewangelie kanoniczne stosują takie określenia na pośmiertne płótna Jezusa, aby wskazać na ścisły związek, zawiniętego w nie ciała zmarłego Jezusa, z kultem oddawanym Jahwe $e^{5}$.

\subsection{Patrystyczne komentarze o całunie}

Charakterystyczne są również patrystyczne komentarze do wymienionych tekstów ewangelicznych. Nie jest ich wiele, ale wskazują, że egzegeci antyku chrześcijańskiego, wprawdzie nieliczni, zauważali te wzmianki o pochówku Jezusa w całunie, wyciągając $\mathrm{z}$ nich wnioski głównie natury moralnej i teologicznej. Do tego stosowali najczęściej interpretację alegoryczną lub typologiczną.

Ewangelia według Marka. I tak Beda Czcigodny (VII/VIII wiek) w Komentarzu do Ewangelii Marka ${ }^{6}$ podkreśla prostotę pogrzebu Jezusa, która ma być interpretowana jako upomnienie dla ludzi bogatych, aby wyzbyli się próżności. Przy tej okazji objaśnia zwyczaj Kościoła dotyczący sprawowania Eucharystii na ołtarzu nakrytym nie jedwabiem lub barwionym płótnem, lecz obrusem $\mathrm{z}$ naturalnego lnu na pamiątkę całunu, w który owinięto ciało Jezusa zdjęte z krzyża i złożone do grobu:

Próżność bogatych, którzy nie potrafią się powstrzymać przed okazywaniem bogactw nawet $w$ grobach, została potępiona przez prosty pogrzeb Pana [...]. Stąd pochodzi również zwyczaj Kościoła, żeby ofiara ołtarza nie była celebrowana owi-

5 Por. B. Frale, Całun Jezusa Nazarejczyka, s. 368-374.

6 Zob. 4, 15, 46 (Corpus Christianorum Series Latina 120, 638). 
nięta w jedwab czy płótna barwione, ale naturalny len, tak jak ciało Chrystusa zostało owinięte w czyste płótno ${ }^{7}$.

Ewangelia według Mateusza. Pisarz antyku chrześcijańskiego Orygenes (II/III wiek) wskazuje na oczyszczającą moc ciała Jezusa, obejmującą zarówno lniane płótno, w które było po śmierci owinięte, jak i cały grób, w którym było złożone ${ }^{8}$. Żyjący zaś w IV wieku Hilary z Poitiers zauważa w Komentarzu do Ewangelii św. Mateusza $(33,8)$ - posługując się egzegezą alegoryczną - że owo płótno z grobu Jezusa oznacza Kościół, który rozszerzył się, aby objąć także pogan, jak to miało - w jego rozumieniu - być objawione Piotrowi, gdy zwierzęta czyste i nieczyste zstępują z góry na wielkim płótnie (por. Dz 10,9-12: kai katabainon skeuos ti hos othonen $)^{9}$. I nie bez racji można przypuszczać - zauważa - że „w obrazie tego prześcieradła kryje się obraz pogrzebania Kościoła w Chrystusie (por. Rz 6,4; Kol 2,12), ponieważ zarówno w nim, jak i w wyznaniu Kościoła zgromadzą się różnorakie zwierzęta, czyste i nieczyste"10. Ta sama Ewangelia przyciągnęła również uwagę Hieronima (IV/V wiek). On to, przypominając, że Józef „zabrał ciało Jezusa i owinął je w czyste płótna” $(27,59)$, objaśnia według rozumienia duchowego, „że ciało Pana należy owinąć nie w złoto, klejnoty czy jedwab, ale w czyste płótno. Chociaż i takie jest znaczenie, że w czyste płótno owinął Jezusa ten, kto przyjął Go szczerym umysłem"11.

Ewangelia według Łukasza. Spośród komentatorów Łukaszowego przedstawienia pustego grobu Jezusa i pozostawionych w nim szat (lnianych płócien) na uwage zasługuje Efrem Syryjczyk (306-373), założyciel szkoły teologicznej w Edessie, autor licznych pism napisanych po syryjsku, nierzadko rymowaną prozą $^{12}$. Do autentycznych, $\mathrm{z}$ grupy pism egzegetycznych, zalicza się między innymi pełen poezji i symboliki Komentarz do czterech ewangelii zebranych w jedno [Diatessaronu $]^{13}$, cenny ze względu na zawarte w nim nauczanie eklezjologiczne i chrystologiczne ${ }^{14}$. W nim Efrem, komentując rozdział 24 odnosi się najpierw

7 Zob. Ewangelia według św. Marka, wyd. pol. tomu przygot. L. Misiarczyk, s. 198.

8 Por. Ewangelia według św. Mateusza 14-29, wyd. pol. tomu przygot. T. Skibiński, s. 308.

9 Ibidem, s. 308-309.

10 Ibidem, s. 310.

11 Zob. Hieronim ze Strydonu, Komentarz do Ewangelii według św. Mateusza, s. 209.

12 Por. Luca, a cura di A.A. Just (jr), s. 524-525, 528.

13 Zob. L. Leloir, Corpus Scriptorum Christianorum Orientalium (dalej: CSCO), t. 137, 145/Arm 1-2, Paris-Louvain 1953-1954.

14 Por. Nowy słownik wczesnochrześcijańskiego piśmiennictwa, wyd. 2 przepr. i uzup. przygot. M. Starowieyski przy współpracy W. Stawiszyńskiego, Poznań 2018, s. 297-299. 
do opowiadania o kobietach (Marii Magdalenie, Joannie i Marii, matce Jakuba), wracających od grobu Jezusa (24,8-11), których relacja wydała się apostołom „czczą gadaniną” i dlatego „nie dali im wiary”. Zdecydowali się sami udać do grobu i znaleźli go pusty (bez ciała Jezusa) i pozostawione tylko lniane szaty. Ten fakt wymownie komentuje Efrem, pisząc, że Jezus wyzbywa się swych (pogrzebowych) szat, „aby Adam mógł ponownie wejść do raju w stan, w którym go pozostawił, czyli nagi"15.

Dla Efrema Chrystus jest „Panem symboli” i „skarbnicą wszelkich symboli”" ${ }^{\prime 16}$ W komentarzu do Diatessaronu również odnosi się do ukrytych w symbolach znaczeń. Takim symbolem są lniane szaty Jezusa, stanowiące w grobie Jego odzienie. Efrem w ich pozostawieniu w grobie dostrzega świadome działanie Jezusa, ponieważ dzięki Jego zmartwychwstaniu, Adam musiał wejść do raju bez ubrania, aby tym wyrazić przywrócony mu stan, jaki posiadał zanim zgrzeszył. Opuszczał niebo (raj), będąc ubrany, teraz - według Efrema - musi się z tego wyzwolić, zanim do niego powróci. Pozostawienie tych szat jest symboliczne. Efrem widzi w tym tajemnicę zmartwychwstania. Skoro Pan zmartwychwstał w chwale bez ubrania (szaty pogrzebowej), to i my - pisze Efrem „powstaniemy z naszymi uczynkami, a nie z naszymi szatami”17.

Ewangelia według Jana. Dwa miejsca, w których wspomniane są przez Jana płótna pośmiertne Jezusa, zauważone zostały w odniesieniu do J 19,40 przez Orygenesa, Augustyna i Bedę Czcigodnego, a do J 20,5-7 przez Jana Chryzostoma i Euzebiusza z Cezarei.

Ad J 19,40. Augustyn w dziele De consensu evangelistarum (O zgodności ewangelistów - powstało ok. 400 roku) dostrzega fakt, utrwalony tylko w Ewangelii Jana, że ciało Jezusa pochowane zostało nie tylko przez Józefa z Arymatei, ale także przy udziale Nikodema, przemilczanego przez synoptyków. To on mógł - według Augustyna - przynieść inne płótna, dodając je do tych, które kupił Józef z Arymatei. Jan, niejako uwzględniając tę możliwość, napisał, że Jezus był owinięty w płótna (nie w płótno - 1.poj.). Niezależnie od tego, że głowa Jezusa została owinięta chustą, a całe ciało owinięte bandażami, jedne i drugie wykonane były z lnianego płótna, można powiedzieć za pierwszymi trzema ewangelistami, i jest to pełna prawda - jak pisze Augustyn - że ciało Jezusa za-

15 Luca, s. 525.

16 Por. Ephraem Syrus, Hymnus de fide, CSCO 154, s. 46 - cyt. za: A. Uciecha, Egzegeza biblijna $w$ komentarzach syryjskich Afrahata, Efrema, Iszodada $z$ Merw i Teodora bar Koni, s. 678. Ponadto zob. A. Kowalski, Adam i Ewa jako dzieci w egzegezie syryjskiej, s. 117-122; A. Skórzewska, Teologia symbolu $w$ dziełach św. Efrema, s. 143-156; J.W. Żelazny, Język symbolu jako charakterystyczny wymiar teologii św. Efrema, s. 799-808.

17 Zob. Efrem, Komentarz do Diatessaronu, 21, 23 - cyt. za: Luca, s. 528. 
winięto „W lniane płótno” (l.poj.). I dalej rozwija tę myśl, chcąc godzić ze sobą przekazy ewangelistów, że użyte przez nich wyrażenie „Iniana szata” odnosi się do wszystkich tekstur użytych przy pochówku Jezusa, gdyż wykonane były $\mathrm{z} \ln \mathrm{u}^{18}$.

Komentarz Bedy Czcigodnego, zawarty w In Marci Evangelium expositio (Wykład Ewangelii Marka), powstałym na przełomie VII i VIII wieku, jest niezwykle lakoniczny. Nawiązuje on do decyzji papieża Sylwestra I z IV wieku (zob. paragraf 2.3.2. w niniejszym artykule). Przypomina on, że eucharystię sprawuje się w Kościele, „zgonie z utrwalonym zwyczajem, nie na jedwabiu lub złotym płótnie, lecz na czystym lnianym materiale"19.

Orygenes zaś (II/III wiek) nadał szacie pogrzebowej Jezusa znaczenie moralne. Zwraca się w Commentariorum in Epistolam B. Pauli ad Romanos (Komentarz do Listu św. Pawła do Rzymian) do chrześcijanina z przestrogą: „Jeżeli nadal żyjesz dla grzechu, nie możesz być pochowany z Jezusem lub znaleźć się w Jego nowym grobie, ponieważ twoje stare ja żyje i nie może wejść w nowe życie”. Pismo święte inspirowane przez Ducha Świętego - pisze Orygenes - ukazując nowy grobowiec Jezusa, w którym został On pochowany, podkreśla, że Jego ciało zostało owinięte czystą (w znaczeniu rytualnym) szatą (całunem). Ten szczegół jest istotny. Poucza on, że „kto chce zostać pochowany wraz z Jezusem przez chrzest, musi wiedzieć, że nic ze starego jego stanu nie powinno zostać wniesione do nowego, nic nieczystego nie może się znaleźć w czystej lnianej szacie"20 (5.8.4).

Ad J 20,5-7. Jan Chryzostom, kapłan działający w Antiochii pod koniec IV wieku, pozostawił po sobie 88 homilii do Ewangelii św. Jana (391 rok). $\mathrm{W}$ jednej z ostatnich (85) ukazał - stosownie do zapisu komentowanej Ewangelii - jak apostołowie, Piotr i Jan, na wieść usłyszaną od kobiet, pobiegli do grobu Jezusa. Jan Chryzostom, komentując to, co zobaczyli, tj. pozostawione w grobie lniane szaty / płótna dostrzegł w nich znak zmartwychwstania Jezusa.

Jego homilia skupiła się na kwestii, czy ciało Jezusa zostało skradzione z grobu. Argumentuje, że złodzieje nie rozebraliby najpierw ciała; nie zadaliby sobie trudu, aby usunąć z głowy chustę, zwinąć ją i położyć na innym miejscu

18 Zob. Augustyn, De consensu evangelistarum, 3.23.60; za: John 11-12, ed. by Joel C. Elowsky; general ed. Thomas C. Oden, Downers Grobe, s. 333-334. Por. Augustyn św., O zgodności ewangelistów, tłum. J. Sulowski, Warszawa 1989. Ponadto zob. D. Zagórski, Jezus Chrystus w 'De Consensus evangelistarum librii quattuor' św. Augustyna, s. 68-76.

19 Beda Venerabilis, In Marci Evangelium exposito, 4.15; cyt za: John 11-12, s. 334.

20 Commentariorum in Epistolam B. Pauli ad Romanos, w: Der Römerbriefkommentar des Origenes. Kritische Ausgabe der übersetzung Rufinus, Buch 4-6, Freiburg 1997. Cytat za: John 11-12, ed. by Joel C. Elowsky; general ed. Thomas C. Oden, s. 334. 
niż płótna. Zapewne zabraliby ciało $\mathrm{w}$ takim stanie, jak je złożono do grobu. Tym bardziej, że Ewangelista napisał, iż ciało Jezusa pochowane zostało wraz z dużą ilością mirry, która sprawia, że „płótno przykleja się do ciała nie mniej mocno niż ołów". Jan Chryzostom kończy ten wywód stwierdzeniem, że złodziej nie byłby tak głupi, aby poświęcić tyle wysiłku na drobiazgi ${ }^{21}$.

Podobny sposób myślenia prezentuje Euzebiusz z Cezarei, gdy komentuje ten tekst wcześniej, na przełomie III i IV wieku, w piśmie do Marinusa ( $A d \mathrm{Ma}$ rinus), żołnierza z Cezarei (supplement 2). Dowodzi w nim, że wbrew sugestii ewangelicznej Marii ludzie nie ukradli ciała Jezusa z grobu. Kto zabiera ciało zmarłego - pisze - nie pozostawia płócien, bo czynność ich zdjęcia wymaga czasu i złodziej mógłby zostać przyłapany na swoim uczynku. Pozostawione płótna potwierdzają tylko zmartwychwstanie Jezusa. Dalszy ciąg jego wywodu ma charakter teologiczny. Bóg, który przemienia ciało upokorzone - pisze Euzebiusz - w ciało uwielbione (chwalebne), czyni to mocą, która w Nim mieszka; przemienia je w coś boskiego. Pozostawione płótno jest takiemu ciału zbędne i obce naturze ciała uwielbionego ${ }^{22}$.

\section{Całun w literaturze apokryficznej}

Całun, służący do pochówku Jezusa, jest też wielokrotnie wzmiankowany w chrześcijańskiej literaturze apokryficznej. Ponieważ nie daje się precyzyjnie zdefiniować tego, co kryje się pod terminem „literatura apokryficzna”23, należy to zjawisko literackie tylko krótko opisać, aby zdawać sobie sprawę, do jakich źródeł będziemy się odnosić. Najogólniej można przyjąć, że na zbiór apokryfów składają się utwory o tematyce biblijnej, które nie zostały przyjęte do kanonu chrześcijańskiego, choć niejednokrotnie do tego pretendowały. Autorzy ich podają się za postacie nowotestamentowe, sytuując swe pisma $\mathrm{w}$ znanym w starożytności i średniowieczu zjawisku pseudoepigrafii. Apokryfy, z których będziemy korzystać, powstawały w wielu językach i reprezentują różne gatunki literackie. Motywy ich tworzenia były niejednorodne. Jedne pragnęły uzupełniać przekazy zawarte w kanonicznych księgach Nowego Testamentu, inne propagować doktrynę, odmienną od apostolskiej, którą podzielała większość wspólnot kościelnych ze swymi przywódcami religijnymi. Na ogół te pierwsze

21 Zob. Jan Chryzostom, Homilie na Ewangelie Jana, 85.4 - cyt. za: John 11-12, s. $340-341$.

22 Zob. ibidem.

23 Por. Ecrits apocryphes chrétiens, t. 1, s. XXV; M. Starowieyski, Barwny świat apokryfów, s. 7-13. 
były wyrazem lokalnych religijności ludowych, drugie różnych sekt religijnych i nierzadko ich przywódców, pragnących propagować swe przekonania religijne. Ich rola kulturotwórcza jest do dzisiaj mało doceniana. Nie można również ich badać bez dużej dozy ostrożności i nie odróżniać zawartego w nich przekazu nierzadko legendarnego od ściśle historycznego, cechującego inne źródła. Przez to ich specyfika nie zawsze może sprostać naszym oczekiwaniom badawczym. Zwłaszcza rekonstruowanie dziejów Jezusa i Kościoła, bez krytycznego (historycznego, literackiego i doktrynalnego) ich traktowania, byłoby niedopuszczalnym błędem metodycznym. Przy prezentacji wybranych tekstów apokryficznych (w porządku chronologicznym), dotyczących całunu, należy o owych uwarunkowaniach koniecznie pamiętać.

\subsection{Ewangelia [według] Hebrajczyków (I wiek)}

Najstarsza wzmianka o całunie Jezusa i losach owego płótna pochodzi z apokryfu zatytułowanego Ewangelia Hebrajczyków, który - niestety - zaginął, ale przekaz o nim zachował się w dziele Hieronima (331?-419) De viris illustribus, datowanym na lata 392-393, i u Epifaniusza z Salaminy (315?-403) w Panarion. Przypuszcza się, że cytowana przez nich ewangelia może pochodzić z końca I wieku. J. Danielou, badacz antycznego chrześcijaństwa, przesuwał nawet czas jej powstania na okres przed 70 rokiem, i wskazywał na Jerozolimę jako miejsce jej napisania lub - może nieco szerzej - na środowisko palestyńskie. Językiem oryginału był dialekt syro-chaldejski (tj. język aramejski), zapisywany hebrajskimi literami. Następnie przetłumaczono ją na grecki, ale ten przekład, z którego mógł korzystać Orygenes, również zaginął ${ }^{24}$. Za czasów Hieronima używali ją judeochrześcijanie (nazarejczycy) z okolic Aleppo (wówczas Berea) oraz ebionici (uważani za heretyków) ${ }^{25}$. Jedni i drudzy używali Ewangelii Mateusza w jakiejś pierwotnej wersji. Epifaniusz tak charakteryzuje to pismo:

24 Por. J. Daniélou, Teologia judeochrześcijańska, s. 36-37.

25 Tak nazarejczycy, jak i ebionici byli judeochrześcijanami. Na istotne różnice między nimi wskazał już w pierwszej połowie II wieku Justyn Męczennik (ok. 140 r.) w Dialogu $z$ Żydem Tryfonem (rozdz. 45-47), czyniąc rozróżnienie na tych judeochrześcijan, którzy przestrzegają Prawa Mojżeszowego (Tory), ale nie zmuszają do tego innych (nazarejczycy), oraz tych, którzy nie tylko sami je przestrzegają, ale także wymagają tego od innych (ebionici są postrzegani przez Justyna jako heretycy, choć sami tak się nie definiowali - por. A. Welburn, Początki chrześcijaństwa, s. 84). Por. Justyn Męczennik, 1 i 2 Apologia. Dialog $z$ Żydem Tryfonem, s. 206-210. 
Uznają oni Ewangelię Mateusza, [...] której używają jako jedynej, i którą nazywają według Hebrajczyków.. Ta ewangelia Mateusza, która jest w ich posiadaniu, nie jest kompletna, ale sfałszowana i zniekształcona ${ }^{26}$.

Natomiast w nocie na temat nazarejczyków twierdził, że Ewangelia według Mateusza, którą ci zachowali, była nadzwyczaj kompletna. Daniélou rozstrzyga ten tekstologiczny dylemat stwierdzeniem, że ebionici mieli z pewnością ten sam tekst, co nazarejczycy, a ponadto przeróbkę tego tekstu w sensie heterodoksyjnym, która być może była jedynie komentarzem do pewnych jej części. Ten właśnie tekst jest nazywany Ewangelią ebionitów ${ }^{27}$, a podstawowy Ewangelia Hebrajczyków. O tej drugiej pisze Hieronim:

[...] również tzw. Ewangelia według Hebrajczyków, przetłumaczona niedawno przeze mnie na język grecki i łaciński; korzysta z niej często Orygenes. Po opisie Zmartwychwstania Zbawiciela czytamy w owej Ewangelii: „Pan zaś, gdy oddał sindon [całun, otulinę lub opończę - K.P.; płaszcz - Starowieyski] słudze kapłana, przyszedł do Jakuba i objawił się mu" (por. 1 Kor 15,7) ${ }^{28}$.

Kim był ów „sługa kapłana” wymieniony w powyższym tekście? Egzegeci rozważają możliwość pomyłki kopisty, który wstawił słowo puero (uczeń) w miejsce oryginalnego Petro (Piotr); później ktoś połączył to słowo puero ze sługą kapłana, wzmiankowanym w Mk 14,47. A zatem po tej korekcie tekstualnej passus ten można by tak odczytać: „Pan zaś, gdy oddał sindon Piotrowi, poszedł i objawił się Jakubowi [...]"29.

Daje się wyprowadzić z tego wniosek, że tradycja o całunie funkcjonowała w pierwotnym chrześcijaństwie w przekazie ustnym lub pisanym, być może jeszcze przed spisaniem kanonicznych ewangelii, i próbowano ją łączyć z osobą Piotra apostoła. Przytoczony tekst wprowadza do niej pewną odmienność w relacji do kanonicznego przekazu ewangelicznego, polegającą na tym, że to sam Jezus miał przekazać swój pośmiertny całun Piotrowi (teksty kanoniczne nic o tym nie mówią). Zgodnie $\mathrm{z}$ tym tłumaczeniem święty przedmiot pozostał w rękach pierwsze-

26 Epifaniusz, Panarion, XXX, 3 i 13.

27 Por. J. Daniélou, Teologia judeochrześcijańska, s. 71.

28 Zob. Apokryfy Nowego Testamentu. Ewangelie apokryficzne, cz. 1, s. 103-104. K. Romaniuk, komentując ten tekst Hieronima, twierdzi, że oddanie syndonu służącemu „wskazuje na realność i prawdziwość zmartwychwstania: nie ukradziono więc ciała Jezusa (Mt 28,11-15)" - ibidem, przyp. 98.

29 Zob. I. Wilson, Całun turyński, s. 113; A. Marion, G. Lucotte, Tunika z Argenteuil i Całun Turyński, s. 24-25. 
go spośród apostołów, co mogłoby oznaczać, że późniejsi chrześcijanie przechowywali całun Jezusa.

\subsection{Ewangelia Piotra (II wiek)}

Ewangelia Piotra powstała w języku greckim, przed 200 rokiem (prawdopodobnie ok. $130 \mathrm{roku}$ ), w środowisku judeochrześcijańskim, prawdopodobnie w Syrii. Tekst jej znał Orygenes (zm. 256) i go cytował. Większy fragment ewangelii zapisanej na papirusie został odkryty dopiero w 1886 roku. Pseudoepigraf przypisywano Piotrowi i dlatego nadano mu tytuł Ewangelia Piotra. Pod względem treści wykazuje ona podobieństwo do Ewangelii Mateusza, choć w szczegółach różni się od niej. Traktuje ona o męce i zmartwychwstaniu Jezusa $^{30}$. Odnośnie do całunu odnajdujemy w niej zapis: „On [Józef z Arymatei] wziąwszy Pana obmył Go, owinął w prześcieradło i złożył do własnego grobu zwanego ogrodem Józefa" (6.24). W porównaniu z ewangeliami kanonicznymi nowością jest stwierdzenie, że ciało Jezusa, przed owinięciem w prześcieradło, zostało obmyte.

\subsection{Akta Piłata}

\subsubsection{Ewangelia Nikodema (Akta Piłata) (IV wiek)}

Apokryf, wielokrotnie nawiązujący do całunu, jest utworem niezwykle skomplikowanym. Pierwotną jego wersję przypisywano Nikodemowi, uczonemu żydowskiemu wiele razy wzmiankowanemu w kanonicznych ewangeliach, który miał na piśmie utrwalić swoje wspomnienia. Następnie próbowano nadać utworowi powagę urzędową i w tym celu zaczęto go nazywać raportem Piłata (Akta Piłata). Utwór, uchodzący najpierw za pamiętnik możnego Żyda, postrzegano następnie jako urzędowy dokument rzymskiego urzędnika ${ }^{31}$. Powstał prawdopodobnie w IV wieku, ale najstarsze fragmenty mogą pochodzić z II wieku ${ }^{32}$; w średniowieczu stał się niezwykle popularny i uważano go za dokument historyczny. Czytamy w nim:

[...] A oto był pewien mąż imieniem Józef, członek rady, mąż dobry i sprawiedliwy. [...] On to zwrócił się do Piłata i poprosił go o ciało Jezusa. I zdjął je z krzyża,

30 Por. Apokryfy Nowego Testamentu. Ewangelie apokryficzne, cz. 2, s. 616-617.

31 Zob. ibidem, s. 633.

32 A. Marion, G. Lucotte, Tunika z Argenteuil i Całun Turyński, s. 23. 
owinął w czyste prześcieradło i złożył do swego nowego grobu, w którym nikogo dotąd nie pochowano. (11.3).

Gdy jednak Żydzi usłyszeli, że Józef poprosił o ciało Jezusa, zaczęli poszukiwać jego i owych dwunastu mężów, którzy mówili, że On się nie narodził z cudzołóstwa, oraz Nikodema i wielu innych, którzy stanęli przed Piłatem i mówili o Jego dobrych uczynkach. [...] Józef stanął przed nimi i rzekł do nich: Dlaczego oburzacie się na mnie za to, że poprosiłem Piłata o ciało Jezusa? Oto złożyłem je w moim grobie i owinąłem je w czyste prześcieradło i położyłem kamień przy wejściu do grobu [...] (12.1).

Postępowanie Józefa zostało przez Żydów ocenione negatywnie i potępione, a on, oskarżony przez nich, znalazł się w więzieniu, skąd cudownie miał go uwolnić Jezus:

A On [Jezus] wziąwszy mnie za rękę podniósł mnie z ziemi i spłynęła na mnie rosa wody. [...] On zaś rzekł do mnie: „Nie jestem Eliaszem, ale Jezusem, którego ciało ty pogrzebałeś”. I rzekłem do Niego: „Pokaż mi grób, w którym Cię złożyłem”. On zaś, trzymając mnie za rękę, zaprowadził mnie do miejsca, gdzie go pogrzebałem i pokazał mi prześcieradło i chusty, w które owinąłem Jego głowę. Wtedy dopiero poznałem, że to Jezus, i oddałem mu cześć, i rzekłem: „Błogosławiony, który przychodzi w imię Pańskie”. (15.6).

W apokryfie topos całunu został połączony z osobą Józefa z Arymatei. W porównaniu z ewangeliami kanonicznymi epizod ten został w nim znacznie rozbudowany i umieszczony w kontekście prześladowań chrześcijan, zwolenników Jezusa, przez Żydów. Znamienna jest też w nim wzmianka o swoistej „antyewangelii” żydowskiej, według której Jezus urodził się w wyniku cudzołóstwa, a Jego matka miała być nierządnicą, przez co posiadał status społeczno-religijny mamzera, to jest osoby pozbawionej wszelkich praw ${ }^{33}$. We fragmentach, w których mowa o prześcieradle i chustach, dostrzega się w tym zgodność $\mathrm{z}$ tradycją Janową.

\subsubsection{Notabene}

Z tego samego okresu (początek IV wieku) pochodzi również decyzja papieża Sylwestra I (314-335), którą znamy z Liber Pontificalis. On to:

33 Por. J. Iluk, Żydowska politeja i Kościół w imperium rzymskim u schyłku antyku, t. II, Gdańsk 2010; Jezus i chrześcijanie w źródłach rabinicznych, Kraków 2012. 
postanowił, aby ofiara ołtarza nie była sprawowana ani na jedwabiu, ani na farbowanym płótnie, lecz na czystym lnie, jak też ciało Pana naszego Jezusa Chrystusa pochowane zostało w lnianym całunie (in sindonem): tak mają być celebrowane $\mathrm{msze}^{34}$.

Na tej podstawie uprawnionym wydaje się przypuszczenie, że tradycja dotycząca całunu Jezusa już w IV wieku ma zasięg powszechny. Widać również, że nie budzi wątpliwości rodzaj materiału, z jakiego był on wykonany, skoro wyłącznie lniane obrusy mają być używane do nakrywania ołtarzy (stołów), na których sprawowano eucharystię.

\subsubsection{Appendix. list biskupa Epifaniusza z Salaminy do Jana, biskupa Jerozolimy (ok. 390 roku)}

Na uwagę zasługuje również list biskupa Epifaniusza z Salaminy na Cyprze do biskupa Jerozolimy Jana. Nie dotyczy on wprost całunu Jezusa, lecz jakiegoś płótna bardzo podobnego do niego. Podróżując pod koniec IV wieku po Palestynie, Epifaniusz znalazł się w miejscowości Anablatha. To, co zobaczył w tamtejszym kościele, wprawiło go w osłupienie:

Po tym, jak podszedłem bliżej, zobaczyłem zapaloną lampkę oliwną i zapytałem, co to za miejsce. Powiedziano mi, że jest to kościół [w miejscowości Anablatha]; wtedy zdecydowałem się wejść do środka, aby się pomodlić. Odkryłem, że w środku powieszono u drzwi długie, pomalowane płótno, na którym znajdował się obraz człowieka na podobieństwo Chrystusa albo jakiegoś świętego; jednak nie przypominam sobie dokładnie. Zaledwie to zobaczyłem, wpadłem w wielką złość, konstatując, że we wnętrzu kościoła powieszono obraz człowieka wbrew autorytetowi Świętych Pism; i tak zerwałem to płótno i poradziłem gorąco zwierzchnikom, aby dali owo płótno na cele dobroczynne, ażeby użyto go do owinięcia i pogrzebania ciała jakiegoś zmarłego biedaka ${ }^{35}$.

Z tego powodu biskup Epifaniusz zwrócił się w liście do miejscowego biskupa Jerozolimy, Jana, informując go o swej interwencji. Odkrył on w odwiedzonym kościele coś, co przypomina nam dzisiaj kształtem całun turyński (on, oczywiście, takiego skojarzenia nie miał). Na owym płótnie (bliżej nieokreślonym) miał być namalowany obraz człowieka, przypominający Chrystusa lub

34 Postanowienie ogłoszone w Rzymie zgromadzonym blisko 300 biskupom; zob. Liber Pontificalis I-XCVI (usque ad annum 772). Księga Pontyfików 1-96 (do roku 772), s. *61.

35 Zob. Patrologia Graeca, red. J.P. Migne, 43, kol. 390-391. Za: B. Frale, Całun Jezusa Nazarejczyka, s. 21. 
jakiegoś świętego. Zaniepokoiło go to, czemu wyraz dał w liście. Można przypuszczać, że podobne wizerunki były już mu znane, skoro do nich się odwołał. Tylko przywołanie szerszego kontekstu historycznego może wyjaśnić reakcję biskupa.

W IV wieku trwał we wspólnotach kościelnych spór, dotyczący kultu obrazów i praktyki posługiwania się nimi przez chrześcijan. Epifaniusz opowiadał się przeciw używaniu obrazów do celów kultycznych, ponieważ - nie tylko w jego przekonaniu, ale też na przykład Euzebiusza, biskupa Cezarei Nadmorskiej - naruszało to starotestamentowy zakaz (i tym samym autorytet Świętych Pism) czynienia jakichkolwiek wizerunków osób boskich (por. Pwt 5, 8 i Wj 32) ${ }^{36}$. Wiązało się to z szerszą kwestią judaizacji i rejudaizacji w Kościele oraz stopniowym zrywaniem z partykularyzmem żydowskim na rzecz uniwersalizmu chrześcijańskiego, który to proces zainicjowany został już w latach czterdziestych i pięćdziesiątych I wieku przez Pawła z Tarsu. Po części spór dotyczący obrazów został już rozstrzygnięty na Soborze Nicejskim (325), na którym wskazywano na konieczność rozróżniania czci oddawanej wyłącznie Bogu, od uhonorowania i oddawania szacunku obrazom i relikwiom. Niemniej widać, że po siedemdziesięciu latach od soboru kontrowersje w tej sprawie nie wygasły.

Poza tym jeden szczegół zawarty w liście jest znamienny. Płótno, które ujrzał Epifaniusz, musiało mieć coś wspólnego z grzebaniem ciał zmarłych. Jego długość świadczyłaby, że mogło przypominać całun pośmiertny. Nie wiadomo, czy wcześniej już wykorzystano go do tego celu? Czy przedstawiony na nim obraz miał przypominać zmarłego w nim pochowanego? Biskup Epifaniusz nie oburzył się z powodu umieszczenia w kościele przedmiotu, który w rozumieniu judaizmu byłby nieczysty i wprowadzał nieczystość do miejsca, w którym się znajdował, i na tych, którzy mieliby z nim kontakt. Sam dotyka tego płótna; zrywa je i poleca, aby je wykorzystano na cele dobroczynne, owijając w nie ciało zmarłego jakiegoś biedaka.

W tym kontekście powstaje teoretyczne pytanie: czy możliwe byłoby przechowywanie pośmiertnego płótna Jezusa, jeżeli takie by się zachowało, w społeczności chrześcijan? Zapewne część wspólnot miałaby dylemat, czy okazać szacunek i kult wobec takiej relikwii-obrazu, czy też dostrzegać w przechowywaniu wizerunku Jezusa naruszenie starotestamentowego Prawa? Nawet biskup Euzebiusz, wielki autorytet III-IV wieku w środowisku nie tylko palestyńskim, przeciwny był portretowaniu Jezusa, Maryi i świętych, dopuszczając tylko przedstawianie tych osób za pomocą symboli lub pod postaciami, na-

36 Zob. Nowy słownik wczesnochrześcijańskiego piśmiennictwa, s. 309-312 (hasło: Epifaniusz z Salaminy). 
wiązującymi do przypowieści ewangelicznych. Jeżeli zatem całun Jezusa istniał w środowisku palestyńskim, to musiał być skrywany przed częścią judeochrześcijan, aby nie został, jako przedmiot nieczysty, zniszczony. Co dla jednych byłoby zapewne bezcenną relikwią, dla innych nieczystością i źródłem utraty czystości rytualnej.

\subsection{Męczeństwo Piłata (Ewangelia Gamaliela) (V wiek)}

Apokryf zaliczany do Cyklu Piłata nastręcza liczne problemy tekstologiczne, literackie i historyczne. Prawdopodobnie najstarsza jego wersja została zredagowana po arabsku i była przekazywana jako dwie homilie Cyriaka, biskupa Bahnasa (Oksyrynchos), o którym niewiele wiemy; czas jego posługi zapewne nie przekracza XIV wieku ${ }^{37}$. Wersję etiopską tych homilii z obszernym komentarzem opublikował po raz pierwszy (po francusku) M.A. van der Qudenrijn w 1957 roku, nazywając drugą jej część (Męczeństwo Piłata), zresztą nietrafnie, Ewangelia Gamaliela ${ }^{38}$.

Pismo przedstawia prokuratora Poncjusza Piłata, znanego również z procesu Jezusa, opisanego w kanonicznych ewangeliach, niemal jako świętego męczennika, który za wyznanie wiary w zmartwychwstałego Chrystusa, pada ofiarą starszyzny żydowskiej. Pojawiają się w niej również inne postacie, w tym Gamaliel, znany z Dziejów Apostolskich $(5,34)$, którego Martyrologium Romanum wymienia jako świętego. Rzekomo napisana przez niego ewangelia różniła się od innych. W rzeczywistości jest to pseudoepigraf, prawdopodobnie z z V wieku.

Wielokrotnie wzmiankowane są w niej płótna pogrzebowe Jezusa (29 razy). Miał je widzieć Piłat, który przybył do grobu Jezusa i stwierdzić: „Wiem, że człowiek, który był w nie owinięty, rzeczywiście powstał z martwych”. Po czym wziął tkaninę i pocałował ją, a następnie podał centurionowi, a ten całując płótno, dotknął nim swoje niewidome oko i odzyskał wzrok. Zaskoczeni Żydzi nie byli w stanie wyjaśnić tego, co się stało. „Wielu zaczęło wątpić, czy rzeczywiście zabili Mesjasza i wycofali się w ciszy”.

Apokryf mówi, że płótna pogrzebowe Jezusa zatrzymała żona Piłata, Procula, która już w czasie procesu Jezusa ostrzegała męża, aby nie robił mu nic złego, ponieważ jest on sprawiedliwy (por. Mt 27,19). Ponadto Piłat nakazał królowi Herodowi [Agrypie] naprawić wszystkie „błędy prawne” popełnione

37 Por. Apokryfy Nowego Testamentu. Ewangelie apokryficzne, cz. 2, s. 712-713.

38 „Le Figaro Literaire” z 13 kwietnia 1957. Korzystam z wersji angielskiej przetłumaczonej 14 lipca 2002 - zob. https://basileia785.wordpress.com/2018/01/22/ewangelia-gamaliela/ (dostęp: 16.03.2020). 
w procesie przeciw Jezusowi. Ten, za radą sanhedrynu, miał prosić Piłata o zgodę na przesłuchanie setnika i strażników. Domagał się również zwrotu dwóch płócien (otulin) wziętych z grobu Jezusa, „ponieważ wszystkie materiały użyte do pochówku są nieczyste według prawa Mojżeszowego”. Na przesłuchanie rzymskich żołnierzy Piłat się zgodził, natomiast odmówił zwrotu prawdziwych otulin (płócien pogrzebowych), ponieważ będąc Rzymianinem, nie był związany żydowskim prawem.

Apokryf wprowadza do przekazu o całunie Jezusa nowy wątek: dwa płótna $\mathrm{z}$ jego grobu wchodzą w posiadanie żony Piłata, Proculi. Mają one moc cudotwórczą i są przez nową właścicielkę traktowane jako relikwie po Jezusie. Natomiast Żydzi widzą w nich źródło nieczystości rytualnej (zgodnie ze swoją tradycją funeralną, która każdego, kto miał kontakt $\mathrm{z}$ ciałem zmarłego lub jego rzeczami użytymi przy pochówku, staje się nieczysty) i chcą je zniszczyć. Można się zastanawiać, czy tylko z tego powodu pragną ich zniszczenia, a nie dlatego, że stanowiły dla chrześcijan, pozostających względem nich religijną grupę opozycyjną i zwalczaną, najcenniejsze relikwie. Procula, nie będąca Żydówką, nie musiała stosować się do przepisów prawa żydowskiego, bo ją nie obowiązywały. Z tego powodu Piłat odmówił Żydom zwrotu płócien.

\subsection{Tradycja gruzińska (IV-VI wiek) - działalność ewangelizacyjna Ninony}

Wątek całunu podjęty też został w późniejszej tradycji gruzińskiej (druga połowa średniowiecza), łączonej z wcześniejszą działalnością św. Ninony (Niny), ewangelizującej Gruzję w IV wieku. Na krótko przed śmiercią przekazała swemu otoczeniu, że - będąc w młodości w Jerozolimie - uzyskała różne wiadomości o przedmiotach związanych z męką Pańską. Był to czas szczególnych poszukiwań arma Christi. Do nich zaliczano także pośmiertne „płótna Chrystusowe”. Według jej przekazu, miały one być w posiadaniu żony Piłata, a następnie oddane św. Łukaszowi, a ten „schował je w miejscu, znanym tylko sobie”. Spośród nich sudarion miał osobną historię. Został on - rzekomo - odnaleziony przez Piotra, który je „wziął i schował, ale nie wiemy, czy zostało kiedykolwiek odnalezione"39. Przypuszcza się, że złożono go w jakimś klasztorze nad Jordanem (Gerasimosa?).

Tradycja gruzińska potwierdza zatem ciągłość przekazu religijnego o całunie. Poszerza dotychczas znany krąg osób, mających z nim kontakt: Procula,

39 Por. I. Wilson, Całun turyński, s. 114. Przywołuje on badania z początku XX wieku M. i J.O. Wardropa i F.C. Conybear'a (The Life of St. Nino, „Studia Biblica et Ecclesiastica” [Oxford] 5: 1900). 
św. Łukasz, św. Piotr. Pojawia się w nim domniemane miejsce jego ukrycia: nad Jordanem.

\subsection{Ewangelia dzieciństwa arabska (po VII wieku)}

Apokryf znany jest również pt. Arabskie życie Jezusa, będący parafrazą Syryjskiego życia Maryi z V wieku. To utwór kompilacyjny, zawierający wyraźną polemikę z islamem, co pozwala na jego ogólną datację po VII wieku. Należy do literatury ludowej, bez większego znaczenia historycznego i teologicznego. Nie wnosi on do poszukiwań toposu całunu czegoś szczególnie nowego. Odnotowano w nim, że „Jusuf [z Arymatei] owinął [ciało Jasu] w całun z nowej tkaniny i wyperfumował je mirrą i aloesem" 40 .

\subsection{Appendix: Listy biskupa Brauliona z Saragossy (590-651)}

Swoistym komentarzem do przytoczonych wątków na temat całunu, pochodzących z literatury apokryficznej, jest fragment listu autorstwa biskupa Brauliona z Saragossy z VII wieku. W swoich Listach, cieszących się poczytnością w wizygockiej Hiszpanii, napisał do opata Taiusa:

W tym czasie wiedziano o wielu rzeczach, które się zdarzyły, lecz które nie zostały zapisane; na przykład co się tyczy sudarionu i płócien, w które zawinięte zostało ciało naszego Pana, czytamy, że zostały one znalezione, ale nie wiemy, czy zostały zachowane. Nie sądzę jednak, aby apostołowie nie pomyśleli o zachowaniu tych i innych relikwii dla przyszłych czasów ${ }^{41}$.

Jeżeli zatem pośmiertne płótna Jezusa zostały zachowane, jak wykazały nasze poszukiwania $\mathrm{w}$ źródłach literackich, to w żadnym $\mathrm{z}$ nich nie ma mowy o tym, że na całunie Jezusa (płótnach) widoczna była Jego podobizna lub jej ślad. Jedyny, dość zastanawiający szczegół, pochodzi z liturgii biskupa Brauliona (rytu mozarabskiego), sprawowanej w Hiszpanii. Illatio na Wielką Sobotę zawiera zastanawiające zdanie: „Piotr przybiegł z Janem do grobu i zobaczył na płótnach świeże ślady (vestigia) zmarłego i zmartwychwstałego”. I. Wilson, komentując ten zapis, dostrzega w nim „utrwaloną pamięć o jakiejś formie wizerunku na płótnach odnalezionych przez Piotra i Jana. Trudno jednak wycią-

40 Por. Apokryfy Nowego Testamentu. Ewangelie apokryficzne, cz. 1, s. 405-406, 434.

41 Zob. Patrologia Latina, red. J.P. Migne, vol. 80, 689. Por. I. Wilson, Całun turyński, s. 114. 
gać wnioski z tak słabej przesłanki”"42. Niemniej to pierwszy przekaz, co ważne, pochodzący dopiero z VII wieku, łączący pośmiertne płótna Jezusa z obecnymi na nich śladami (odbiciami).

\section{Apokryfy o wizerunkach Jezusa}

Chrześcijaństwo od swego zarania rozwijało się w dwóch obszarach kulturowo-religijnych. Adekwatnie do tego wyznawcami Jezusa zmartwychwstałego stawali się judeo- i etnochrześcijanie. Pierwsi wywodzili się ze świata żydowskiego, drudzy spośród politeizmu, najczęściej grecko-rzymskiego. Ich kulturowe uwarunkowania powodowały różne odniesienia do obrazów i figur używanych w nowym, chrześcijańskim kulcie. Judeochrześcijanie nie byli w swych poglądach, dotyczących wizerunków, jednorodni. Najbardziej radykalni, próbujący godzić judaizm z nową religią, uważali, że droga do chrześcijaństwa powinna prowadzić przez Torę. Strzegli jej nakazów i zakazów, w tym tego, który mówił, że „Nie uczynisz sobie posągu ani żadnego obrazu, co jest na niebie wysoko, albo na ziemi nisko, lub w wodzie poniżej ziemi" (Pwt 5,8). To przez wieki powstrzymywało kolejne pokolenia judeochrześcijan przed czynieniem jakichkolwiek wizerunków Jezusa, Maryi i świętych. Niekiedy nawet zmuszali do tej praktyki bardziej liberalnych współbraci Żydów (i etnochrześcijan), którzy jednak sukcesywnie zrywali z partykularyzmem żydowskim, w tym z zasadą czystości rytualnej, oraz mentalnie - co było niezwykle trudne - wpisywali się w Kościół uniwersalny, z jego doktrynalnymi i etycznymi kanonami, mającymi głównie paulińskie korzenie. Poszukiwaniem rozwiązania owego napięcia, istniejącego we wspólnotach kościelnych, kulturowo przemieszanych, było przyzwolenie na wykonywanie dzieł sztuki, obrazów i rzeźb, w tym wizerunków Jezusa, pod warunkiem, że były to przedstawienia idealistycznie albo symboliczne. Natomiast istniał pośród nich silny sprzeciw wobec realistycznego obrazowania postaci Boskich i świętych Kościoła, w taki sposób, aby były niemal ich odzwierciedleniem.

Nie wolno również zapominać o tym, że w obrzędowości ludowej, głównie wśród etnochrześcijan, istniał zwyczaj sporządzania portretów, które przekazywały rzeczywiste rysy oblicza Jezusa, Maryi i apostołów. Niejednokrotnie potępiano ich za te praktyki, które przywódcy wspólnot kościelnych (na ogół intelektualiści chrześcijańscy) uważali za śmieszne, bliskie zabobonom, a nawet za przejaw bałwochwalstwa. Wymownym przykładem, pozwalającym zrozumieć istotę sporu na temat sporządzania obrazów, jest list biskupa Euzebiusza z Ce-

42 I. Wilson, Całun turyński, s. 114. 
zarei Nadmorskiej - wiodącej stolicy biskupiej w Palestynie, nawet ważniejszej niż Jerozolima - do Konstancji, siostry cesarza Konstantyna, która poprosiła go o kopię autentycznego wizerunku Jezusa Chrystusa. Zamiast kopii otrzymała niemal reprymendę, która mentalnie mieściła się w poglądach radykalnych judeochrześcijan, przestrzegających Tory:

Jeśli jednak teraz oświadczasz, że nie prosisz mnie o wizerunek postaci ludzkiej przemienionej w Boga, ale o obraz jego śmiertelnego ciała, takiego jakie było przed Jego przemienieniem, wtedy odpowiadam: czy nie znasz miejsca, w którym Bóg nakazuje, aby nie czynić żadnego obrazu tego, co jest na niebie wysoko, ani tego, co jest na ziemi nisko ${ }^{43}$.

Etnochrześcijanie natomiast, zwłaszcza z cesarstwa rzymskiego, aprobowali praktykę sporządzania realistycznych portretów Jezusa i świętych Kościoła. Znali ją jeszcze z okresu, gdy byli politeistami, i zwyczajem w ich środowisku społecznym było przedstawianie podobizn bliskich zmarłych. Często umieszczano je na grobach. Malowano je też na bandażach mumii (Egipt), aby w ten sposób zachować twarz zmarłej osoby i pamięć o niej. Niektóre są tak precyzyjnie wykonane, że wydają się niemal fotografiami. Praktyka ta stała się także ich udziałem po przyjęciu chrześcijaństwa. Wymownymi artefaktami, które ją ilustrują, są ikony z okresu justyniańskiego z klasztoru św. Katarzyny na Synaju (VII wiek). Przedstawiają one Jezusa i św. Piotra, a ich artystyczną proweniencję odkrywamy wówczas, gdy zestawimy je $\mathrm{z}$ tradycyjnymi portretami rzymskimi epoki cesarstwa. Trafnie określa ten zwyczaj B. Frale, która uważa, że praktyka "przechowywania w domu portretów Jezusa i apostołów rodzi się z tego samego nawyku oddawania czci, właściwego Rzymianom, a także składania ofiar penatom, czyli zmarłym członkom rodzin [...]"44.

Ten trwający w obrębie chrześcijaństwa spór musiał mieć wpływ również na historię całunu Jezusa i przekazu o nim. Potęgował on napięcie „ikonograficzne", bo z jednej strony w części środowisk chrześcijan postrzegano całun jako niezwykłą pamiątkę po Chrystusie, cenną również dla jego najbliższych uczniów, którzy byli Żydami. Z drugiej zaś strony, prowadził do refleksji i dylematów, powstałych pod wpływem Prawa żydowskiego, czy kontakt z nim nie powoduje zaciągnięcia nieczystości rytualnej, ponieważ rzecz ta dotykała zmarłego ciała Jezusa. Ponadto, jeśli znajdował się na nim wizerunek Jego osoby (nie wiadomo jak uczyniony), całun dodatkowo stwarzał problem, gdyż 
stawał w opozycji do przepisu toraicznego, zabraniającego sporządzania wszelkich obrazów i oddawania im czci.

W tym kulturowo-religijnym kontekście należy widzieć problematykę wizualizacji Jezusa, którą egzemplifikują przytoczone poniżej zestawione źródła apokryficzne. Prześledzenie ich powinno pomóc zrozumieć, czy całun z odbiciem postaci Jezusa, bez rozstrzygnięcia kwestii, czy taki się zachował, mógł znaleźć dla siebie miejsce w jakiejś judeochrześcijańskiej wspólnocie kościelnej, spotkać się z poszanowaniem, a nawet czcią i być przedmiotem szczególnie cennym w aspekcie religijnym.

\subsection{Przekaz Euzebiusza z Cezarei (III-IV wiek) i Ewangelia gruzińska (po XI wieku)}

W apokryfach najobszerniejszy opis materialnego obrazu Jezusa odnajdujemy w Ewangelii gruzińskiej. Jej datacja jest skomplikowana, a materiał literacki eklektyczny: posiada wątki z antyku chrześcijańskiego (spory monofizyckie) i drugiej połowy średniowiecza (wypraw krzyżowych). Redakcja utworu odbywała się przez wiele wieków. Dlatego trudno określić miejsca jego powstawania. Utwór czerpie wiele zarówno z ewangelii kanonicznych, jak i apokryficznych. Posiada też elementy własne, gdzie indziej niewystępujące. Zaliczamy go do gruzińskiej literatury ludowej oraz literatur kaukaskich ${ }^{45}$.

W opis całościowej działalności Jezusa, stanowiący główny przedmiot narracji, wpleciony został wątek dotyczący króla Abgara, będący zapewne przeróbkę legendy o tymże władcy. Jej najstarszą wersję podaje już Euzebiusz z Cezarei w Historii kościelnej ${ }^{46}$, która nie przynależy do apokryfów, lecz do literatury patrystycznej antyku chrześcijańskiego.

Otóż cierpiący na trąd toparcha Edessy, Abgar V zwrócił się do Jezusa z prośbą o uzdrowienie, wyznając jednocześnie wiarę w jego mesjańskość i synostwo Boże. Przesłał jednocześnie Jezusowi szatę, która nie była uszyta igłą (całodzianą) ${ }^{47}$. Chrystus miał udzielić Abgarowi listownej odpowiedzi, powiadamiając, że osobiście do niego nie przybędzie, ale po wniebowstąpieniu pośle do niego swojego posłańca (apostoła), Tadeusza, który wyleczy go oraz pobłogosławi króla i jego królestwo.

45 Por. Apokryfy Nowego Testamentu. Ewangelie apokryficzne, cz. 1, s. 204-205.

46 Zob. Historia ecclesiastica 1, 13; por. Euzebiusz z Cezarei, Historja kościelna, s. 43-48.

47 Notabene: w różnych tradycjach jej pochodzenie jest odmiennie określane - np. dar mędrców ze Wschodu; obecnie trzy miejsca na świecie szczycą się jej posiadaniem: Trewir, Argenteuil i gruzińska Mccheta. 
Gdy poseł ujrzał Jezusa, nie miał już chęci odejść od niego; przywołał malarza i kazał mu namalować wizerunek Jezusa. Malarz zaczął malować na papierze oblicze Jezusa. Namalował go najpierw jako mężczyznę w sile wieku. Lecz Jezus ukazał mu się w postaci starca. Malarz przekreślił [obraz] i namalował go jako starca z siwą brodą. Malarz więc bardzo się zdziwił. Jezus zapytał go: 'Dlaczego jesteś zdziwiony?'. Malarz odrzekł: 'Panie, pragnę namalować oblicze Twoje dla naszego króla i nie mogę'. Jezus zapytał: 'Dlaczego malujesz?', na co malarz odrzekł: 'Król nasz bardzo pragnie Cię zobaczyć. Wydał nam bowiem rozkaz: jeśli nie przyjdzie sam, to namalujcie Go i przynieście mi Jego obraz, a ja przez to samo już wyzdrowieję. Po raz drugi usłyszał Jezus o wierze Abgara. Wtedy Jezus wziął chustę lnianą i położył ją na swojej twarzy, a wówczas na chuście odbiło się oblicze Jezusa takie, jakim było w rzeczywistości. Jezus wręczył tę chustę posłowi i powiedział: 'Weźmijcie ten obraz dla Abgara ode Mnie wraz z moją modlitwą i błogosławieństwem. Zostanie on wybawiony trzy razy. Najpierw przez ten obraz, potem przez Tadeusza, i po raz trzeci przez chrzest' ${ }^{48}$.

Zgodnie z tą obietnicą Abgar wyzdrowiał, a jego poddani uwierzyli w Jezusa Chrystusa. Euzebiusz dodaje jeszcze datę wydarzenia (rok 340 według ery Sleleukidów, tj. ok. 28 lub 29 roku po Chr.), odnotowując, że to, co zapisał, przetłumaczył z języka syryjskiego ${ }^{49}$.

Z powyższych przekazów wynika, że w gruzińskiej tradycji, nieuwarunkowanej judeochrześcijańskimi zwyczajami, posiadanie obrazu Jezusa nie było naganne. Również starożytna Edessa, stolica królestwa Osroene, zwłaszcza w czasach władców chrześcijańskich, nie respektowała „antyikonograficznych” przepisów judeochrześcijaństwa. Krytyka historyczna, podejmując próbę identyfikacji władcy Edessy, który rzekomo skierował prośbę do Jezusa, uważa Abgara V (panował w latach 4 przed Chr. do 7 po Chr. i 13-50 po Chr.) i epizod z nim związany za legendarny. Literacka jej forma, do której się odwołujemy, zwłaszcza przytoczona przez Euzebiusza, powstała prawdopodobnie w środowisku syryjskim na przełomie II i III wieku za Abgara VIII lub IX (władcy chrześcijańscy). Z czasem edesski wizerunek Jezusa (na płótnie / ręczniku) postrzegano jako „ikonę ikon” - acheiropit, nie ręką ludzką uczyniony. Nie znamy jego dziejów od II do VI wieku. Dopiero od VI wieku znajdujemy poświadczenie tego artefaktu, traktowanego jako święty i nazywanego, od XII wieku, mandylionem, co należy tłumaczyć jako ręcznik, chusta.

Legenda dotycząca Abgara, rozpowszechniona została od połowy średniowiecza, za sprawą pisma cesarza Konstantyna Porfirogenety z X wieku pt. Opo- 
wieść o wizerunku $z$ Edessy ${ }^{50}$, sporządzonego z okazji przeniesienia (translatio) mandylionu z Edessy do Konstantynopola (15 VIII 944 roku), i czytania go w czasie liturgii Kościoła wschodniego (Bizancjum, obszaru Słowiańszczyzny wschodniej i południowej). Pismo miało formę homilii świątecznej, przeznaczonej na coroczne święto przeniesienia całunu, obchodzone 16 sierpnia.

Nie należy zapominać, że już w V-VI wieku autentyczność korespondencji między królem Abgarem a Jezusem została podważona przez takie autorytety ówczesnego Kościoła, jak Hieronim ${ }^{51}$ i biskup Augustyn z Hippony ${ }^{52}$, których opnie zaważyły na wydaniu w VI wieku Dekretu Gelazego ${ }^{53}$, uznającego między innymi ową korespondencją za tekst apokryficzny (nieautentyczny). Współczesne badania, podobnie oceniają ów przekaz. Wskazują natomiast na apotropeiczną funkcję wizerunku Jezusa dla Edessy. Niemniej ten, który jest znany z VI wieku, nie może być utożsamiony z tym, o którym mowa w najwcześniejszej wersji legendy. Tamten był kolorowym obrazem twarzy Jezusa, późniejszy - zwłaszcza w środowisku bizantyjskim - został przekształcony w cudowny odcisk postaci Jezusa na płótnie, ale wówczas nikt nie był świadomy tej ewolucji, jaką wizerunek przeszedł. W obszarze Bizancjum istniało kilka obrazów o podobnych cechach, które konkurowały o pierwszeństwo. Jeden z tych mandylionów został przeniesiony do Konstantynopola w 944 r., gdzie pozostał do czwartej krucjaty. Następnie został sprzedany Ludwikowi IX (1214-1270) z Francji, po czym zniknął w chaosie rewolucji francuskiej. Możemy tylko przypuszczalnie określić wielkość i kształt konstantynopolitańskiego mandylionu dzięki dwom kopiom zachowanym w Genui i Rzymie ${ }^{54}$. Nie ma jednak - jak wynika z badań A. Nicolottiego - żadnych dowodów na to, że mandylion z Edessy był całunem Jezusa, ani że pokazywał całe Jego poranione i ukrzyżowane ciało. Argumentów za ich utożsamianiem nie odnajdujemy, a te

50 Pełny tytuł: Konstantyna [Porfirogenety] z łaski Chrystusa cesarza rzymskiego opowieść o wizerunku z Edessy. Oparte na różnych relacjach historycznych opowiadanie o świętym obrazie Chrystusa, Boga naszego, niesporządzonym ręka i wysłanym do Abgara oraz o tym, jak go przeniesiono z Edessy do tej zażywającej szczególnej pomyślności królowej wśród miast - Konstantynopola. Zob. Konstantyn Porfirogeneta, Opowieść o wizerunku z Edessy, w: I. Wilson, Całun turyński, s. 322-340 (dodatek C); ponadto por. M. Tycner-Wolicka, Opowieść o wizerunku z Edessy, Kraków 2009.

51 Commentaria in Ezechielem, Ad 44, 29-30. Powstał w latach 414-416.

52 Contra Faustum manichaeum 28, 4; De consensu evangelistarum 1, 7, 11.

53 Decretum Gelasianum de libris recipiendis et non recipiendis (Dekret Gelazego o książkach, które należy przyjąć i których nie należy przyjąć). Zob. Dokumenty synodów od 431 do 504 , s. $305^{\star}-322^{\star}$.

54 Zob. A. Nicolotti, From the Mandylion of Edessa to the Shroud of Turin, Leiden-Boston 2014. 
które są przytaczane, nie budzą zaufania, ponieważ odnoszą się do źródeł nie stricte historycznych, lecz mających znaczenie dla historyków kultury. Wprawdzie dla A. Nicolott historia całunu z Turynu zaczyna się od przełomu XIII i XIV wieku (zachowuje w tym zakresie fundamentalistyczne podejście), jak mogło to wynikać z ustalonej jego datacji przy pomocy rozpadu węgla radioaktywnego ${ }^{55}$, wszystko inne to w jego rozumieniu bajka. Dlatego nie utożsamia on obiektu z Edessy i Konstantynopola z autentycznym całunem Jezusa, o którym mówią ewangelie kanoniczne, ani z tym z Turynu. Całun Jezusa jest dla niego nadal przedmiotem poszukiwań.

\subsection{Cykl Piłata}

Następne opisy powstania obrazów Jezusa, które posiadały cudowną moc, odnajdujemy w tzw. Cyklu Piłata, w utworach literackich, w których decydującą rolę odgrywał Piłat. Interesują nas z tej grupy trzy pisma o tytułach Śmierć $P i$ łata, Zemsta Zbawiciela i Uzdrowienie Tyberiusza.

\subsection{1. Śmierć Piłata}

Sam utwór pochodzi ze średniowiecza i cieszył się dużą poczytnością. Przejęty został z 53 rozdziału Złotej legendy, niezwykle popularnych średniowiecznych żywotów świętych autorstwa Jacobo da Voragine, włoskiego dominikanina, do niej zaś trafił z Historia apostolica. Oryginał zapisany został po łacinie.

Otóż cesarz Tyberiusz, śmiertelnie chory, dowiedział się, że w Jerozolimie jest lekarz imieniem Jezus, który samym słowem leczy wszystkie choroby. Nie wiedział jeszcze, że jego urzędnik Piłat i Żydzi zabili go. Kazał go zatem czym prędzej przysłać do siebie. Wówczas Piłat, do którego rozkaz cesarski dotarł, przyznał, że ów człowiek był złoczyńcą i kazał go ukrzyżować, a wyrok już wykonano. Poseł Tyberiusza, wracając z tą wieścią od Piłata, spotkał po drodze pewną kobietę, Weronikę. Użalał się przed nią, że nie mógł wypełnić zadania powierzonego mu przez cesarza.

Na to odrzekła mu Weronika: 'Gdy Pan mój nauczając wędrował, a mnie było bardzo ciężko znosić Jego oddalenie, chciałam, by mi namalowano Jego podobiznę,

55 Zob. P.E. Damon [i in.], Radiocarbon Dating of the Shroud of Turin, s. 611-615. Badania ustaliły przedział czasowy powstania całunu turyńskiego na lata 1260-1390. Ustalenia te są dzisiaj kwestionowane nie $\mathrm{z}$ powodu zastosowania do badań metody rozpadu węgla radioaktywnego, tylko z powodu błędnych procedur, które zastosowano w ich przeprowadzeniu. Redakcja „Nature” nigdy do tych zarzutów się nie odniosła. 
abym, gdy będę pozbawiona Jego obecności, cieszyła się przynajmniej podobizną Jego postaci. Gdy niosłam płótno malarzowi, aby na nim Go namalował, spotkałam Pana, który mnie zapytał, gdzie idę. Gdy wyznałam przyczynę, wziął ode mnie materiał i oddał mi go z odbitym obrazem Jego świętej twarzy. Jeśli więc na to oblicze spojrzy pobożnie twój pan, będzie się zawsze cieszył dobrodziejstwem zdrowia $^{56}$.

Poseł skłonił Weronikę, aby wraz z obrazem, będącym w jej posiadaniu, udała się do cesarza. Gdy Tyberiusz spojrzał na obraz, „powróciło mu dawne zdrowie" 57 .

\subsubsection{Zemsta Zbawiciela}

Motyw obrazu Jezusa, będącego w posiadaniu Weroniki, znajduje się również w utworze Zemsta Zbawiciela. Utwór powstał we wczesnym średniowieczu, przed IX wiekiem. Chętnie czytali go krzyżowcy ${ }^{58}$. Utwór wskazuje na kobietę, Weronikę, w której posiadaniu był obraz Jezusa. Rzymianie torturami mieli ją zmusić do pokazania obrazu Zbawiciela.

Ona zaś zmuszona wyznała: 'Mam go owinięty czystym całunem, panie mój, i oddaję mu cześć każdego dnia. Welozjanus odrzekł: 'Pokaż mi go'. Wtedy ona pokazała oblicze Pana. Gdy je zobaczył Welozjanus, upadł ze czcią na ziemię, wziął go z ochotnym sercem i z prawą wiarą, owinął go złotym całunem i opieczętował własnym pierścieniem. I uroczyście przysiągł i rzekł: 'Na Pana Boga żywego i zdrowie Cezara, nie zobaczy go więcej człowiek na ziemi, dopóki nie stanę przed obliczem mojego pana Tyberiusza ${ }^{39}$.

Pokazany obraz Tyberiuszowi rzekomo sprawił, że odzyskał zdrowie, po czym on i jego poddani zostali ochrzczeni.

\subsubsection{Uzdrowienie Tyberiusza}

Ten sam motyw obecny jest także w utworze Uzdrowienie Tyberiusza, który sądząc po liczbie zachowanych jego kopii - cieszył się dużą popularnością. Znany jest w języku łacińskim, lecz powstał prawdopodobnie po grecku na obszarze Syrii. Odnajdujemy w nim następujący fragment:

\footnotetext{
56 Zob. Apokryfy Nowego Testamentu. Ewangelie apokryficzne, cz. 2, s. 685.

57 Ibidem.

58 Ibidem, s. 692-693.

59 Ibidem, s. 698
} 
Gdy Tyberiusz August to usłyszał [o Weronice], kazał sobie przedstawić ową niewiastę wraz z obrazem Jezusa Chrystusa. I gdy Tyberiusz ujrzał obraz i kobietę, jego właścicielkę, rzekł do niej: 'Ty zasłużyłaś sobie dotknąć kraju szat Jezusa'. I gdy to powiedział, spojrzał na obraz Jezusa Chrystusa, zadrżał i padłszy na twarz ze łzami, oddał cześć obrazowi Jezusa Chrystusa i natychmiast wyzdrowiał ze swojej choroby i ze zgnilizny swojej rany, którą cierpiał w swoich wnętrznościach. A skoro tylko odczuł moc Boskości poprzez uzdrowienie swojego ciała, dzięki spojrzeniu na obraz natychmiast kazał obdarzyć kobietę Weronikę bogactwem i zaszczytami, i nakazał dać jej majątek z dóbr publicznych, a obraz włożyć w ramy ze złota i cennych kamieni.

Wybrane fragmenty to dość późne świadectwa apokryficznej literatury chrześcijańskiej. Ich bohaterowie to rzymski cesarz Tyberiusz i kobieta o imieniu Weronika. Swego adresata chcą przekonać, że na chrześcijaństwo nawrócił się sam władca imperium rzymskiego, co w aspekcie historycznym jest niedorzecznością. Dokonać się to miało na skutek spojrzenia na przyniesiony mu wizerunek Chrystusa, który posiadał tak cudowną moc, że wyzdrowiał.

Apokryfy te potwierdzają, że świat rzymski i średniowieczna Europa nie stroniła od wizualizacji Jezusa. Ta praktyka przynosić miała ozdrowieńcze skutki i spotykała się wówczas ze społeczną aprobatą i szerzeniem kultu obrazów. Środowisko etnochrześcijan, stanowiące w średniowieczu wyłączny komponent wspólnot kościelnych, otwarte było na wizualizację postaci Jezusa i wykorzystywanie obrazów w kulcie.

\section{Itineraria o całunie}

Nie mniej ważnymi źródłami, w których należy poszukiwać toposu całunu, są itineraria, tj. spisywane przez chrześcijańskich pielgrzymów do Ziemi Świętej (ojczyzny Jezusa i apostołów) relacje, zwykle po powrocie do domu, ale czasami jeszcze w trakcie podróży. Ich celem było wskazanie na to, jak dotrzeć do poszczególnych miejsc świętych i co warto w nich zobaczyć, jak wygląda tam życie religijne, jakie budowle sakralne w tych miejscach wzniesiono ${ }^{60}$.

\subsection{Anonim z Piacenzy (VI wiek)}

Imienia pątnika pochodzącego z Piacenzy, który pozostawił nam swój przekaz o podróży do ojczyzny Jezusa, nie znamy. Pozostał anonimowy. W przybliżeniu

60 Por. Do Ziemi Świętej, s. 22-23. 
udaje się określić czas powstania jego zapisu - ok. 570 roku. Odnotowuje on, że kiedy przybywa nad Jordan:

Na brzegu Jordanu jest grota $\mathrm{z}$ celami dla siedmiu dziewic, które są tam umieszczane jako małe dziewczynki [...]. Na zewnątrz są ludzie, którzy się o nie troszczą. Przybyliśmy do tego miejsca (napełnieni) wielkim szacunkiem, aby się pomodlić, lecz nie widzieliśmy żadnej z nich. W miejscu tym, jak mówią, jest chusta, która była na twarzy Pana. $(12)^{61}$.

Na ogół miejsce to utożsamia się dzisiaj z klasztorem prawosławnym św. Gerasimosa, nieopodal Jerycha. Nie mamy pewności, o jaki artefakt w jego relacji chodzi. Czy jest to ów całun, czy inne płótna pośmiertne Jezusa, które miały być schowane przez św. Piotra? Czy jeszcze jakieś inne relikwie?

\subsection{Opowieść biskupa Arkulfa (VII wiek)}

Opowieści biskupa Arkulfa znamy z przekazu niejakiego Adomnana, który żył na antypodach ówczesnego świata - na wyspie Hy (Iona) u wybrzeży Szkocji. Był on tam opatem klasztoru. Sam nigdy nie odbył podróży do Ziemi Świętej ${ }^{62}$. Jego książka powstała

dzięki opowieściom galijskiego biskupa Arkulfa, który udał się do Jerozolimy, by odwiedzić święte miejsca, po czym przewędrował całą Ziemię Świętą, jak też Damaszek, Konstantynopol, Aleksandrię i wiele wysp na morzu. Gdy wracał statkiem do ojczyzny, został przez burzę wyrzucony na zachodzie wybrzeża Brytanii i tak dostał się do wspomnianego sługi Chrystusowego, Adomnana. Tu ów wykształcony i znający miejsca święte podróżnik został życzliwie przyjęty i jeszcze życzliwiej wysłuchany ${ }^{63}$.

Tę relację z VII wieku znamy dzięki innemu Irlandczykowi, Bedzie Czcigodnymu, który opisał to w Liber de locis sanctis ${ }^{64}$. Otóż Adomnan z Hy tak pisze o jednym z miejsc świętych, które odwiedził (rozdz. IX):

1. Także o najświętszej chuście Pańskiej, którą w grobie przykryta była Jego głowa, wiemy dzięki opowiadaniu świętego Arkulfa, który widział on na własne oczy. [...] 2. Mniej więcej przed trzema laty najświętszy lniany całun skradziony

\footnotetext{
61 Ibidem, s. 214.

62 Ibidem, s. 237-243.

63 Ibidem, s. 238.

64 Zob. XVIII, 4-5.
} 
niegdyś z Grobu Pańskiego po zmartwychwstaniu przez pewnego wierzącego (w Chrystusa) Żyda i przez długi czas ukrywany, został po wielu latach odnaleziony i wrócił jako znak i dar dla całego ludu. [...] 9. Jednak po pięciu pokoleniach lniany całun przestał przechodzić w spadku na wierzących i dostał się w ręce innych, niewierzących Żydów. [...] 10. Skoro wierzący Żydzi z ludu, którzy usłyszeli prawdziwą historię chusty Pańskiej, zaczęli gwałtownie domagać się jej zwrotu i jęli ze wszystkich sił walczyć o odzyskanie jej z rąk Żydów niewierzących. Spór ten podzielił lud Jerozolimy na dwa stronnictwa, to jest na wierzących i niewierzących ${ }^{65}$.

Spór musiał rozstrzygnąć król Saracenów Mavias (właściwie Muawija). Chcąc przekonać się, czy chusta jest relikwią, miał ją wrzucić w płomienie, ale ogień nie mógł jej zniszczyć, bo uniosła się nienaruszona, a potem zaczęła opadać na stronę chrześcijan, aż spoczęła w ich ramionach, a ci

15. [...] złożyli chustę w relikwiarzu w kościele, zawinąwszy ją w inny lniany całun. 16. Brat nasz Arkulf widział ją, gdy pewnego dnia została wyjęta z relikwiarza i całował ją wraz z tłumem ludu, a także sam, w kościele podczas służby Bożej. Ma ona około ośmiu stóp długości [ok. 2,4 m] ${ }^{66}$.

Przez jakiś czas panowało przekonanie, że całun, oglądany przez biskupa Arkulfa, otrzymał w darze w 797 roku król Karol Wielki, a jego wnuk Karol Łysy podarował go opactwu św. Korneliusza w Compiègne, gdzie przez 900 lat był przechowywany i otoczony czcią. Całun ten uległ całkowitemu zniszczeniu w czasie rewolucji francuskiej. Nie mógł być zatem płótnem, które dałoby się zidentyfikować z całunem turyńskim. Poza tym jego rozmiary są inne. Nie mógł też być tym samym całunem / mandylionem łączonym z Edessą, ponieważ biskup Arkulf widział go w Jerozolimie. W Edessie musiało być zatem inne płótno otaczane czcią.

\section{Epilog i wnioski}

\subsection{Relacja Roberta de Clari}

Cenna w kontekście naszych poszukiwań jest jeszcze drobna wzmianka z XIII wieku w relacji krzyżowca pikardyjskiego Roberta de Clari z sierpnia

65 Zob. Do Ziemi Świętej, s. 257-258.

66 Ibidem, s. 259-260. 
1203 roku, który widział w Konstantynopolu, na krótko przed konfliktem między krzyżowcami i Bizantyjczykami

w kościele Najświętszej Panny Maryi Blacherneńskiej, przechowywany sydoine, w który Pan nasz został owinięty i który jest podnoszony pionowo w każdy piątek, tak żeby postać (figure) naszego Pana była na nim wyraźnie widoczna. I nikt z Greków ani z Francuzów nie wiedział, co się stało z tym sydoine po zdobyciu [przez krzyżowców] miasta ${ }^{67}$.

Potwierdza ona obecność mandylionu / całunu w Konstantynopolu na początku XIII wieku. Jak on trafił do stolicy Bizancjum? Znane są pewne przekazy, które pozwalają łączyć nam historię całunu z Konstantynopola z Edessą (dzisiejsza Şanlıurfa), wspomnianą wcześniej w przytaczanych powyżej źródłach. W VI wieku miano znaleźć w murach Edessy tkaninę określaną jako „mandylion z Edessy”. Ewagriusz Scholastyk (526-600) datuje odnalezienie płótna na 544 rok (czas walk z Persami). Relikwia miała zapewnić cudowne zwycięstwo nad innowiercami, lecz jest to tylko legenda. W rzeczywistości mandylion został znaleziony wcześniej. W roku 525 nastąpiła powódź, która znacznie uszkodziła miasto (opisana przez Prokopiusza z Cezarei), a Justynian I Wielki rozkazał odbudować zniszczone podczas kataklizmu budowle. Wówczas podczas prac odnaleziono mandylion. Przechowywano go następnie w kościele Bożej Mądrości (według Ewagriusza Scholastyka). Akta Tadeusza również mówią o odnalezieniu płótna w Edessie, używając na jego określenie pojęcia tetradiplon („złożony we czworo”; tzn. na osiem części). Dlatego kopie mandylionu z Edessy ukazywały tylko samą twarz Jezusa (I. Wilson udowodnił, iż da się ułożyć całun turyński w ten sposób). Czy zatem mandylion z Edessy i całun turyński to ten sam artefakt? Tradycja o królu Edessy Abgarze łączy mandylion z Edessą, a ikonografia tylko po części tę hipotezę wspomaga.

W X wieku mandylion został przewieziony do Konstantynopola (kwiecień 944). W latach 945-959 spisano, wspomnianą już powyżej Opowieść o wizerunku $z$ Edessy, która zawierała wiele legend oraz nieścisłości, mająca odpowiednik w Synaksarionie Kościoła Konstantynopolitańskiego z tych samych lat, opraco-

67 I. Wilson, Całun turyński, s. 209. Jest to relacja pikardyjskiego krzyżowca Roberta de Clari zachowana w rękopisie przechowywanym w Królewskiej Bibliotece w Kopenhadze - sygn. 487. Zob. Robert de Clari, Zdobycie Konstantynopola, Poznań 1997; ponadto zob. G. Wieszołek, IV krucjata na podstawie kronik Geoffroya de Villehardouin i Roberta de Clari. Jedno wydarzenie różne spojrzenia, Opole 2015. 
wanym między innymi przez Konstantyna Porfirogenetę ${ }^{68}$. Z Konstantynopola całun znika w 1204 roku, po grabieży miasta przez krzyżowców.

Dodatkowo warto przywołać w tym miejscu badania nad całunem turyńskim prowadzone w latach 1973-1978 przez Maxa Frei-Sulzera, szwajcarskiego biologa i kryminologa. Przeprowadził on badanie całunu turyńskiego pod kątem obecności na nim pyłków roślinnych i wyodrębnił ślady 58 gatunków roślin. Na tej podstawie określił domniemaną historię, a raczej geografię jego przemieszczania. Wskazał, że miejsca jego obecności należy łączyć ze starożytną Palestyną, Bizancjum, basenem Morza Śródziemnego i Francją. Jego badania tylko w niewielkim stopniu wpływają na wiarygodność hipotezy utożsamiającej całun $\mathrm{z}$ Turynu $\mathrm{z}$ mandylionem $\mathrm{z}$ Edessy ${ }^{69}$, ale nie dowodzą tożsamości tych artefaktów.

\section{Podsumowanie}

Konkluzja z całości rekonesansu po antycznej i średniowiecznej literaturze chrześcijańskiej oraz niezwykle selektywnie dobranych dokumentach z tego okresu, prowadzi do wniosku, że topos całunu jest w przebadanych źródłach obecny. Fundamentalny przekaz o całunie Jezusa znajduje się w kanonicznych pismach chrześcijańskich - ewangeliach, które miały zasadniczy wpływ na jego podtrzymywanie przez kolejne pokolenia chrześcijan. Religijność ludowa i apokryfy, będące jej ikoną, rozwinęła go, wskazując expressis verbis na rodzaj materiału, $\mathrm{z}$ jakiego wykonane były pośmiertne płótna pogrzebowe Jezusa, oraz domniemane osoby go przechowujące - święci Piotr i Łukasz oraz Piłat i jego żona Procula. Na ogół wskazywane miejsca jego przechowywania były różne, ale też nie wiadomo, czy należy łączyć z nimi tylko jedno płótno i jeszcze jakieś chusty, czy chodzi o różne artefakty (należy się przychylać do tej drugiej konstatacji). Geografia całunu / całunów wiedzie przez Jerozolimę, nad Jordan, do Edessy i Konstantynopola, a następnie do Europy (Francja). W Kościele powszechnym przekaz o całunie znalazł utrwalenie od IV wieku w liturgii (lniane obrusy na ołtarzach). Pojawia się też wśród chrześcijan, zwłaszcza tych wywodzących się z politeizmu grecko-rzymskiego (etnochrześcijan), potrzeba posiadania wizerunku Jezusa, co łączyło się różnymi legendami, w których wiodącymi postaciami stała się Weronika i cesarz Tyberiusz. Wi-

68 W kościele łacińskim podobnym dziełem jest jego Martyrologium. Nie wiadomo, która ze wskazanych prac była wcześniejsza i jakie są między nimi zależności (która była wzorcowa).

69 Zob. M. Frei, Wissenschaftliche Probleme um das Grabtuch von Turin, s. 132-135; por. A. Danin, Botany of the Shroud of Turin, Jerusalem 2010. 
doczny jest również konflikt pomiędzy judeo- i etnochrześcijanami dotyczący w ogóle wizerunków Jezusa. To zapewne utrudniało ewentualne przechowywanie całunu Jezusa i przekaz o tej niezwykłej pamiątce / relikwii, na której miałby się znajdować Jego wizerunek. Wzmiankowany w źródłach całun pełni zwykle funkcję apotropeiczną - kontakt $\mathrm{z}$ nimi przynosi uzdrowienia albo jego posiadanie broni przed niebezpieczeństwem. Całun i chusty zaliczone zostały też w antyczną i średniowieczną aurę poszukiwania i chęci posiadania relikwii po Jezusie (krzyż, włócznia, gwoździe, korona cierniowa, chusty pogrzebowe). Najciekawszym bodaj efektem rekonesansu badawczego jest sukcesywne odkrywanie w kolejnych źródłach elementów przekazu składających się na jego teologię, która się rozwija zwłaszcza od IV wieku. Niemniej żaden z wymienionych w źródłach artefaktów nie posiada cech całunu z Turynu. Koresponduje z nim jedynie przekaz z kanonicznych ewangelii. Nawet mandylion, który sprowadzony został z Edessy do Konstantynopola w X wieku, i to, co o nim wiemy, nie pozwala na utożsamienia go $\mathrm{z}$ autentycznym całunem Jezusa $\mathrm{i}$ całunem z Turynu, który - ten ostatni - po pojawieniu się w Europie w połowie XIV wieku, wywołał wokół siebie spory o autentyczność, i to w samym środowisku kościelnym. Historia tego całunu w zasadzie nie jest udokumentowana w antycznym i średniowiecznym piśmiennictwie chrześcijańskim. Jedynie odnalezione na nim pyłki kwiatowe wskazują na drogę, jaką odbył z Bliskiego Wschodu do Europy, co pokrywa się też z historyczną geografią artefaktów, rekonstruowaną na podstawie przebadanych źródłach.

\section{Bibliografia}

Apokryfy Nowego Testamentu. Ewangelie apokryficzne, cz. 1, Fragmenty. Narodzenie i dzieciństwo Maryi i Jezusa, red. M. Starowieyski; współprac. W. Appel [i in.], Kraków 2003.

Apokryfy Nowego Testamentu. Ewangelie apokryficzne, cz. 2, Św. Józef i św. Jan Chrzciciel. Męka i zmartwychwstanie Jezusa. Wniebowzięcie Maryi, red. M. Starowieyski; współprac. W. Appel [i in.], Kraków 2003.

Augustyn św., O zgodności ewangelistów, tłum. J. Sulowski, Warszawa 1989. (Pisma Starochrześcijańskich Pisarzy, t. 50).

Commentariorum in Epistolam B. Pauli ad Romanos, w: Der Römerbriefkommentar des Origenes. Kritische Ausgabe der übersetzung Rufinus, Buch 4-6, ed. by C.P. Hammond Bammel, Freiburg 1997. (Vetus Latina. Aus der Geschichte der Lateinischen Bible, 33).

Corpus Scriptorum Christianorum Orientalium, Pais-Louvain 1903-.

Damon P.E. [i in.], Radiocarbon Dating of the Shroud of Turin, Nature 1989, no. 337, s. 611-615. 
Daniélou Jean, Teologia judeochrześcijańska. Historia doktryn chrześcijańskich przed Soborem Nicejskim, przekł. S. Basista, Kraków 2002.

Danin Avinoam, Botany of the Shroud of Turin. The Story of Floral Images on the Shroud of Turin, Jerusalem 2010.

Do Ziemi Świętej. Najstarsze opisy pielgrzymek do Ziemi Świętej IV-VIII w., wybór, wstęp, wprowadzenie i oprac. P. Iwaszkiewicz; przedm. M. Starowieyski, wyd. 2, Kraków 2010.

Dokumenty synodów od 431 do 504, układ i oprac. A. Baron i H. Pietras, Kraków 2011. Ecrits apocryphes chrétiens, t. 1, red. F. Bovon et P. Geoltrain, Paris 1997.

Ephraem Syrus, Hymnus de fide, w: Corpus Scriptorum Christianorum Orientalium, 154, Paris-Louvain 1953-1954.

Euzebiusz z Cezarei, Historja kościelna. O męczennikach palestyńskich, z grec. tłum., zaopatrzył wstępem, objaśnieniami, skorowidzami A. Lisiecki, Poznań 1924, s. 48. (Pisma Ojców Kościoła, tom III).

Ewangelia według św. Marka, wyd. pol. tomu przygot. L. Misiarczyk, Ząbki 2009. (Ojcowie Kościoła Komentują Biblię. Nowy Testament).

Ewangelia według św. Marka. Wstęp - przekład z oryginału - komentarz, oprac. H. Langkammer, Poznań-Warszawa 1977.

Ewangelia według św. Mateusza 14-29, wyd. pol. tomu przygot. T. Skibiński, Ząbki 2018. (Ojcowie Kościoła Komentują Biblię. Nowy Testament, Ib).

Frale Barbara, Całun Jezusa Nazarejczyka, przekł. G. Rawski, Kraków 2012.

Frankel Ellen, Platkin Teutsch Betsy, The Encyclopedia of Jewish Symbols, Oxford 2004.

Frei Max, Wissenschaftliche Probleme um das Grabtuch von Turin, Naturwissenschaftliche Rundschau 32: 1979 Hf. 4 s. 132-135.

Hieronim ze Strydonu, Komentarz do Ewangelii według św. Mateusza, tłum. J. Korczak, Kraków 2008. (Źródła Myśli Teologicznej, 46).

Iluk Jan, Żydowska politeja i Kościół w imperium rzymskim u schyłku antyku, t. II, Żydowska antyewangelia. Antyczna tradycja i nowożytne trwanie, Gdańsk 2010.

Jezus i chrześcijanie w źródłach rabinicznych. Perspektywa historyczna, społeczna, religijna i dialogowa, red. K. Pilarczyk i A. Mrozek, Kraków 2012.

John 11-12, ed. by Joel C. Elowsky; general ed. Thomas C. Oden, Downers Grobe, Illinois 2007. (Ancient Christian Commentary on Scripture. New Testament Ivb).

Justyn Męczennik, 1 i 2 Apologia. Dialog z Żydem Tryfonem, tłum. i oprac. L. Misiarczyk, Warszawa 2012.

Konstantyn Porfirogeneta, Opowieść o wizerunku z Edessy, tłum. J. Radożycki, [w:] Wilson Ian, Całun turyński, przeł. i posłowiem opatrzył A. Polkowski, wyd. 2, Warszawa 1985, s. 322-340 (dodatek C).

Kowalski Aleksander, Adam i Ewa jako dzieci w egzegezie syryjskiej, Roczniki Teologiczno-Kanoniczne 30: 1983 z. 1 s. 117-122.

Kowalski Aleksander, Adam i Ewa jako dzieci w egzegezie syryjskiej, Roczniki Teologiczno-Kanoniczne 30: 1983 z. 1 s. 117-122.

Leloir L., Corpus Scriptorum Christianorum Orientalium, t. 137, 145/Arm 1-2, Paris-Louvain 1953-1954. 
Liber Pontificalis I-XCVI (usque ad annum 772). Księga Pontyfików 1-96 (do roku 772), tłum. P. Szewczyk, M. Jesiotr; oprac. M. Ożóg, H. Pietras, Kraków 2014.

Luca, a cura di Arthur A. Just (jr), Roma 2006. (La Bibbia Commentata dai Padri. Nuovo Testamento, 3).

Marion André, Lucotte Gérard, Tunika z Argenteuil i Całun Turyński. Podsumowanie badań, tłum. A. Łatka, Kraków 2008.

Nicolotti Andrea, From the Mandylion of Edessa to the Shroud of Turin. The Metamorphosis and Manipulation of a Legend, Leiden-Boston 2014. (Art and Material Culture in Medieval and Renaissance Europe, vol. 1).

Nowy słownik wczesnochrześcijańskiego piśmiennictwa, wyd. 2 przeprac. i uzup. przygot. M. Starowieyski, współp. W. Stawiszyński, Poznań 2018, s. 309-312 (hasło: Epifaniusz z Salaminy).

Patrologia Graeca, red. J.P. Migne, Paris 1857-1866.

Patrologia Latina, red. J.P. Migne, Paris 1844-1855.

Robert de Clari, Zdobycie Konstantynopola, z jęz. starofrancuskiego przetłum., wstępem i koment. opatrzył Z. Pentek, Poznań 1997.

Skórzewska Agnieszka, Teologia symbolu w dziełach św. Efrema, Ateneum Kapłańskie 153: 2009, z. 1, s. 143-156.

Starowieyski Marek, Barwny świat apokryfów, wyd. 3 popr. i uzup., Poznań 2015.

Tanach u-Brit Chadasza, [Brith Chadasza] transl. from the Greek by F. Delizsch; th ed., Jerusalem 2004.

Tycner-Wolicka Marta, Opowieść o wizerunku z Edessy. Cesarz Konstantyn Porfirogeneta i nieuczyniony ręka wizerunek Chrystusa, Kraków 2009.

Uciecha Andrzej, Egzegeza biblijna w komentarzach syryjskich Afrahata, Efrema, Iszodada $z$ Merw $i$ Teodora bar Koni. Zarys problematyki, Vox Patrum 37: 2017, t. 67, s. 673-688.

Wardrop M. i J.O., Conybear F.C., The Life of St. Nino, Studia Biblica et Ecclesiastica [Oxford] 5: 1900.

Welburn Andrew, Początki chrześcijaństwa. Esseńskie misterium, gnostyckie objawienie, chrześcijańska wizja, Warszawa 1998.

Wieszołek Grzegorz, IV krucjata na podstawie kronik Geoffroya de Villehardouin i Roberta de Clari. Jedno wydarzenie różne spojrzenia, Opole 2015 [praca magisterska: https://www.academia.edu/21561201/IV_krucjata_na_podstawie_ kronik_Geoffroy_a_de_Villehardouin_i_Roberta_de_Clari._Jedno_wydarzenie_różne_spojrzenia (dostęp: 18.03.2020).

Wilson Ian, Całun turyński, przeł. i posłowiem opatrzył A. Polkowski, wyd. 2, Warszawa 1985.

Zagórski Dariusz, Jezus Chrystus w 'De Consensus evangelistarum librii quattuor' św. Augustyna, Studia Włocławskie 14: 2012, s. 68-76.

Zerwick Max, Analysis philologica Novi Testamenti graeci, ed. 3, Romae 1966.

Żelazny Jan W., Język symbolu jako charakterystyczny wymiar teologii św. Efrema. Zarys problematyki, Vox Patrum 30: 2010, t. 55, s. 799-808. 